\title{
Can The Business Model Of Handelsbanken Be An Archetype For Small And Medium Sized Banks? A Comparative Case Study
}

\author{
Morten Kousgaard Larsen, Aarhus University, Denmark \\ Jacob Lange Nissen, Aarhus University, Denmark \\ Rainer Lueg, Aarhus University, Denmark \\ Christian Schmaltz, Aarhus University, Denmark \& True North Institute, United Kingdom \\ Joachim Røjkjær Thorhauge, Aarhus University, Denmark
}

\begin{abstract}
The Danish Banking sector faces increasing requirements regarding regulation and profitability, which especially threatens small and medium sized banks. This study analyzes whether the successful business model of Handelsbanken ('The Handelsbanken Way') can serve as a blueprint for small and medium sized banks. We conduct a comparative case study by interviewing Handelsbanken and the disguised 'Danish Local Bank' (DLB). The DLB is a representative example of small and medium sized Danish banks. This study is structured according to the frameworks from business model implementations and from implied organizational structures.

Using the notion of Osterwalder and Pigneur (2010), this study reveals only minor differences in the business models of Handelsbanken and DLB. Despite the supposedly obvious advantages of 'The Handelsbanken Way,' this study suggests that the financially troubled small and medium sized banks in Denmark will not necessarily benefit from the tactical choice of decentralization unless they incorporate specific adjustments. This study contributes to the existing theory if Handelsbanken's approach to banking can improve the situation of financially troubled small and medium sized banks.
\end{abstract}

Keywords: Business Model; Decentralization; Handelsbanken; Banking; Organizational Structure; Financial Crisis

\section{INTRODUCTION}

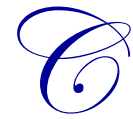

ompared to other banking sectors in the EU, the Danish sector is marked by particularly fierce competition, leading to very low achievable profit margins (The Danish Bankers Association, 2007; Weill, 2013). Simultaneously, the repercussions of the financial crisis have led to stricter regulation. Moreover, shareholders require higher capital reserves of banks in order to signal their financial stability (Schaeck \& Cihák, 2012). The increasing level of equity is expensive and lowers shareholders' return. Coupled with substantial loan write-offs (The Danish Bankers Association, 2013a), it is expected that these factors will force several small and medium sized banks to engage in mergers and acquisitions (M\&A) in order to reach the critical size for survival (Niro Invest APS, 2012). Most of the previous M\&A were not profitable and poorly capitalized (Pasiouras, Tanna, \& Gaganis, 2011).

Handelsbanken's Danish branches outperform its competitors in the Danish market with respect to service, customer loyalty, and satisfaction (EPSI, 2012), as well as cost efficiency (see Table 1). This is mainly achieved through a decentralized organization with a strong focus on cost culture, limiting both actual spending and depreciations on loans. As a result, Handelsbanken is able to maintain higher margins than competitors at significantly lower costs, especially within depreciations on loans. Given this success, it is intriguing to question why smaller Danish banks still adhere to a centralized organizational structure. Hence, we pose the research question: Can the business model of Handelsbanken be an archetype for small and medium sized banks? 
Our comparative case study answers this research question by first determining the Business Models as well as the strategic priorities of the large Group 1 bank "Handelsbanken" and a small Group 3 Danish Local Bank $(\mathrm{DLB})^{1}$ to understand the differences and similarities. Then, we proceed with the tactical choices the two banks have made within their business models. We find that the business models and the strategic priorities of the two banks are almost identical. But when it comes to the specific tactical choices they have made within the limits of their business models, the two banks differ substantially. In particular, DLB is subject to stricter regulation on decentralization as its default risk is higher than the one of Handelsbanken. Furthermore, DLB uses traditional ways of budgeting and to control their operations by variance analyses. Handelsbanken's decentralization allowed for the abandonment of budgets and a switch toward cultural control systems. Furthermore, decentralization enables a more trust-based and output oriented leadership style in Handelsbanken. Finally, DLB has strong local roots that almost obligate the bank to accept customers from the local community that would not necessarily be served by Handelsbanken. We conclude that DLB - even though it has the same business model as Handelsbanken - cannot enhance their operations by copying the well-known 'Handelsbanken Way' of decentralization due to contextual differences in size (and risk) as well as the customer base.

The remainder of the paper is organized as follows: we explain the theoretical backgrounds of our study in Section 2 and derive an appropriate research design in Section 3. Section 4 presents our findings, while Section 5 offers an in-depth discussion of these. Section 6 concludes.

\section{THEORETICAL BACKGROUND}

This section introduces the theoretical concepts of a business model, organizational structure, and the characteristics of a decentralized organization.

\subsection{Business Model and Value Chains in Banks}

So far, the research field of business models is very diverse, and no generally accepted definition of the term has emerged (Zott, Amit, \& Massa, 2011). As a starting point, Amit and Zott (2001, p. 511) suggest that:

"A Business Model depicts the content, structure, and governance of transactions designed so as to create value through the exploitation of business opportunities."

The business models of organizations that pursue the same customers with similar products do not have to be identical (Casadesus-Masanell \& Ricart, 2010; Zott \& Amit, 2008). This originates from the fact that a business model does not have to have a specific content, such as strategic types (Chesbrough \& Rosenbloom, 2002; Magretta, 2002). A business model is rather a conceptual tool, which expresses the logic of a specific firm through its description of the architecture of the firm and the relationships within the firm (Osterwalder \& Pigneur, 2005). The business model defines both the firm's boundaries for value creation and caption (Casadesus-Masanell \& Ricart, 2010; Zott \& Amit, 2008). The explicit focus should be on value creation, as the methods for value capturing are due to strategic decisions (Chesbrough \& Rosenbloom, 2002; Magretta, 2002). When the business model is implemented throughout the organization, it becomes a part of the strategy. It does this by manifesting its choices and systems such as business processes, infrastructure, and organizational structure. Once the strategy and the business model are chosen, an organization continues by making concrete tactical choices (Casadesus-Masanell \& Ricart, 2010). For instance, the organizational structure is not an inherent part of the business model (Osterwalder \& Pigneur, 2005). Hence, it is possible that two organizations have the same strategy and business model but substantially differ in the way they implement these (i.e., their tactical choices).

The later derived business model of DLB and Handelsbanken will be built upon the notion of Osterwalder \& Pigneur (2005) due to the significant resource-based view and focus on the internal environment. Note that the definition of the business model is sufficiently general to be used within different fields.

\footnotetext{
${ }^{1}$ The Danish banking sector is divided into 4 groups. The deciding variable is the working capital, which is defined as the sum of the deposits, equity, issued bonds, and subordinated capital contribution. DLB is a part of Group 3 with a working capital of 5.5 billion Danish Kroner. According to the Danish Bankers' Association's 2012 financial report, Handelsbanken would be a member of Group 1 (Danish Bankers' Association, 2013b; Finanswatch, 2013).
} 
The internal value chain of banks consists of two main blocks: selling products and managing (resulting) risks. The branches sell products (deposits, loans, derivatives, etc.) adjusted to match customers' needs (sales). The subsequent risk profile is adjusted to each banks' risk appetite (risk management). Note that sales and risk management can follow different organizational structures: sales can be localized (in branches) to emphasize proximity to the customer. Risk management of losses is often centralized to benefit from internal hedging and netting to the maximum extent. Risk management of cash flows is often decentralized to better absorb local liquidity shocks (Pokutta \& Schmaltz, 2011). Note that this paper exclusively studies the organizational structure of sales, not of risk management.

\subsection{Organizational Structure and Decentralization}

In general, organizational structure represents levels of the hierarchy within an organization, the accountability of the employees, and the control of the managers. The organizational structure can be seen as a guideline for interaction between the units of an organization. The structure affects formal communication, organizational job status, the degree of access to information, job descriptions, resource allocation, regulations and rules, compliance to and enforcing of rules as well as coordination between activities (March \& Simon, 1958; Thompson, 1967). Decentralization is a feature of organizational structure. It means that the authority to make decisions is delegated from top management to middle managers and employees in responsibility centers within the organization (Carter \& Cullen, 1984; Wong, Ormiston, \& Tetlock, 2011).

\subsection{Characteristics of a Decentralized Organization}

There are many success factors of a decentralized organization, one of them being a matching culture. Management needs to be convinced to have well-educated employees whose judgment can be trusted in order to achieve the organizations vision, mission, and strategy. This often goes together with non-routine jobs that cannot be standardized (Atkinson \& Kaplan, 1998). Furthermore, decentralization is thought to be especially beneficial for organizations that operate in volatile and unpredictable environments. Another success factor of decentralization is a strong information asymmetry between top managers and middle managers. As an example, top management should decentralize resource allocation decisions if the task is too complex for them (Atkinson \& Kaplan, 1998). By choosing a decentralized organizational structure, the decision-making is placed where the relevant information is available. It might be overly complex to communicate all local information to top management when decisions have to be made fast and close to the customer. The time it takes to make a decision is shortened since it does not need approval by the central management (Atkinson \& Kaplan, 1998; Lee \& Whang, 1999). As a consequence, top managers have fewer decisions to consider, allowing them to set the broad policy and strategic direction for the entire organization. Finally, delegating the decision-making to responsibility centers improves the experience of middle managers in decision-making (Carter \& Cullen, 1984). This provides training for the next generation of general managers and will give top managers an indication of who might be able to cope with future challenges. Further, by giving more responsibility to responsibility centers, middle managers can be more ambitious. This may lead to more motivation, higher efforts, innovation, and creative thinking (Atkinson \& Kaplan, 1998). When following a decentralized organizational structure, it is vital that the employees are capable of coping with the increased responsibility given to them (Hersey, Blanchard, \& Natemeyer, 1979).

As to drawbacks, centralized organizations must accept a higher level of formalization, standardized policies, and enforceable deadlines (Fredrickson, 1986). This may lead to an uncertainty among employees about what is expected of them (Hirst, 1981; Marginson \& Ogden, 2005). Appropriate control mechanisms in these organizations are therefore mostly output controls that consider inputs or behaviors of employees to a lesser extent (Merchant \& Van der Stede, 2007). Another disadvantage is an 'us vs. them' feeling that reduces knowledge sharing. It could even encourage the creation of slack and duplicated resources for one's own unit, or a dysfunctional use of shared resources that aims at maximizing profits in a unit, and not in the organization as a whole. Additionally, it becomes harder to coordinate work and efforts of different departments, which may lead to a waste of resources. 


\section{RESEARCH DESIGN}

\subsection{Methodology}

A case study is suitable to answer our research question due to the hermeneutic foundation of the article and newness of the research topic, so it needs to be explored by 'how' and 'why' questions. Our decision to employ this method is further supported by the possibility of integrating a variety of evidence in form of interviews, newspapers, archival data, etc. (Lueg, Nedergaard, \& Svendgaard, 2013; Ryan, Scapens, \& Theobald, 2002; Yin, 2009). For an in-depth understanding of the business models of our sample banks (and their implementations), a comparative case study will be applied. We chose a comparative case study because the banks are closely matched units where the focus of interest is to find an explanation on what causes the variations in performance (for examples, see Goutas \& Lane, 2009; Lueg, Clemmensen, \& Pedersen, 2013). Moreover, a case study is suitable for capturing a process under study in a very detailed and exact way (Flick, 2009; Yin, 2009). Several banks from Group 1 and 3 (the Danish Financial Supervisory Authority grouping criterion) are chosen as a benchmark to Handelsbanken and DLB. Despite the relatively low degree of knowledge obtained through the low number of financial reports, there is no indication that DLB and/or Handelsbanken represent an extreme part of the Danish banking sector.

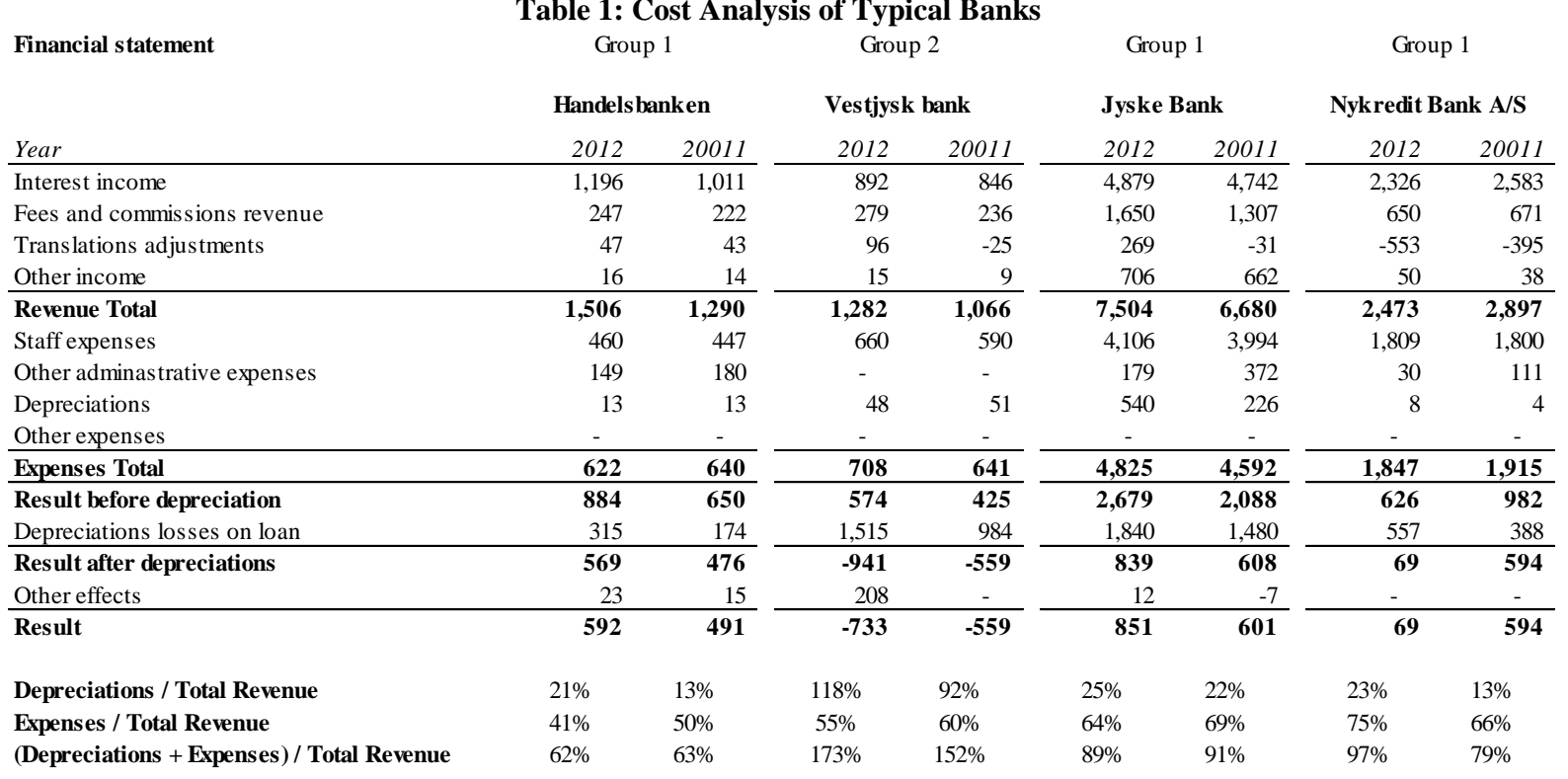


Table 1 cont.

Financial statement

\section{Group 3}

Group 3

\begin{tabular}{|c|c|c|c|c|c|c|}
\hline \multirow[b]{2}{*}{ Year } & \multicolumn{2}{|c|}{ Sparekassen bredebro } & \multicolumn{2}{|c|}{ Østjysk bank } & \multicolumn{2}{|c|}{ Broagers Sparekasse } \\
\hline & 2012 & 20011 & 2012 & 20011 & 2012 & 20011 \\
\hline Interest income & 41 & 39 & 225 & 245 & 66 & 72 \\
\hline Fees and commis sions revenue & 12 & 12 & 69 & 56 & 19 & 15 \\
\hline Translations adjustments & 2 & -0 & 22 & -5 & 5 & 1 \\
\hline Other income & 1 & 0 & 6 & 3 & 1 & 0 \\
\hline Revenue Total & 56 & 50 & 321 & 299 & 91 & 88 \\
\hline Staff expenses & 35 & 34 & 147 & 146 & 60 & 63 \\
\hline Other adminas trative expenses & - & - & - & - & - & - \\
\hline Depreciations & 1 & 1 & 6 & 5 & 5 & 5 \\
\hline Other expenses & 2 & 2 & 8 & 10 & 2 & - \\
\hline Expenses Total & 37 & 36 & 160 & 161 & 66 & 67 \\
\hline Result before depreciation & 19 & 14 & 161 & 138 & 24 & 21 \\
\hline Depreciations losses on loan & 16 & 9 & 364 & 128 & 66 & 14 \\
\hline Result after depreciations & 3 & 5 & -203 & 11 & -41 & 7 \\
\hline Other effects & - & - & - & - & & \\
\hline Result & 3 & 5 & -203 & 11 & -41 & 7 \\
\hline Depreciations / Total Revenue & $28 \%$ & $17 \%$ & $113 \%$ & $43 \%$ & $72 \%$ & $16 \%$ \\
\hline Expenses / Total Revenue & $66 \%$ & $73 \%$ & $50 \%$ & $54 \%$ & $73 \%$ & $76 \%$ \\
\hline (Depreciations + Expenses) / Total Revenue & $95 \%$ & $90 \%$ & $163 \%$ & $96 \%$ & $145 \%$ & $92 \%$ \\
\hline
\end{tabular}

Group 3

Due to the significant number of variables that influence the financial and non-financial performance, a qualitative research method is suitable. This implies that the interviewer and the interviewee have the opportunity to add extra perspectives or in debt explanation in the data gathering process, as they are not restricted by yes/noquestions (Flick, 2009). Our research is aligned with Osterwalder and Pigneur's (2010) theory on business models, and it is therefore necessary to guide the respondents through the different perspectives. These are the main reasons for choosing a semi-structured interview, as open questions enable the respondents to answer freely and go in whichever direction they feel relevant (Flick, 2009; Yin, 2009).

\subsection{Collection and Analysis of Data}

The Danish banking sector is suitable for conducting such a study because Handelsbanken operates in Denmark, and small and medium sized banks account for the predominant share measured in total number. We only consider Handelsbanken's operations in Denmark. As stated above, this study seeks to investigate the usefulness of 'The Handelsbanken Way' in financially troubled small and medium sized banks within Group 3. DLB operates less than 10 branches within a limited regional area. It has less than 200 employees and assets of less than 10 billion Danish Kroner. DLB does not face financial trouble during the timeframe of the analysis. It is, however, seeking ways to consolidate its financial position. The potential limitation of choosing a financially sound bank does not cause bias, as the Danish banks are fundamentally similar. And it is presumed that a financially sound bank is more informative, which can lead to an improved analysis.

We gathered the primary data through qualitative interviews, while the secondary data was publicly available information from reports and publications. The respondents chosen for the interviews are a branch manager from Handelsbanken in Jutland, and the CEO of DLB. Their position and knowledge of their respective banks make them capable of providing valid data through interviews. We improved validity by applying data- and investigator corroboration through the use of multiple sources of evidence and by building a subsequent shared understanding of the collected data (Yin, 2009). Furthermore, the interviewees reviewed this paper. The CEO of DLB chose to remain anonymous. Our key informant from Handelsbanken (Esben Kjeldsen, Aarhus City) highlighted that his expressed views are subjective and personal. They do not necessarily reflect the opinions of Handelsbanken's board members or other branch managers across the globe. 
We analyze the data through coding where the gathered data from the interviews is labeled in categories to identify potential differences and similarities between DLB's and Handelsbanken's approach to banking. The interview categories are based on and related to Osterwalder and Pigneur's (2010) notion of a business model. That way, we ensure the most appropriate comparison between the banks.

\section{FINDINGS ON THE BUSINESS MODELS OF THE BANKS}

Subsequently, we describe the business models of DLB and Handelsbanken according to Osterwalder and Pigneur (2010).

\subsection{Similar Business Models according to the Nine Building Blocks}

\subsubsection{Customer Segments}

To construct a properly functioning business model, it is imperative to understand the customer segments involved (Osterwalder \& Pigneur, 2010). DLB and Handelsbanken serve the segments of private and corporate customers. Within the corporate segment, Handelsbanken is selective on its customers, whereas DLB accepts almost every corporate customer who approach them. This is due to its commitment to serving the local community. Within the private segment, both banks could significantly differentiate along income gaps and personnel needs (e.g., targeting high net worth individuals), but neither DLB nor Handelsbanken employ such a premium strategy.

There is a natural difference regarding the size of the corporate customers that DLB and Handelsbanken can take on their balance sheet. As Handelsbanken is much larger, it can serve larger firms with larger borrowing needs. It handles these larger exposures through specialized teams. Among and even within the two customer segments, needs and problems are not identical. But the value proposition to handle the issues is overall similar.

\subsubsection{Value Propositions}

The value proposition solves a specific problem or satisfies a specific need within or across an organization's customer segments. As DLB and Handelsbanken are financial institutions, the value proposition contains both products and services. This value proposition is split into the segments private and corporate. The product suites of the two banks are financial products such as loans, credit cards, debit cards, insurance, and pensions. These products are subsequently tailored to the needs of customers. Correspondingly, DLB and Handelsbanken offer online banking to both the private and commercial segment, though the applications and use is different according to the customer segment. When compared to those of their nearest competitors, the product offerings of DLB and Handelsbanken are very similar. At the same time, a financial institution like DLB is not able to compete on prices due to its small size. Handelsbanken does not want to compete on prices. As an ulterior strategy, both DLB and Handelsbanken differentiate themselves from their competitors by offering high-quality customer services.

\subsubsection{Channels}

The connection to the customer can be established through either direct or indirect distribution channels. These channels indicate how the value propositions are delivered to the different customer segments (Osterwalder \& Pigneur, 2010). DLB and Handelsbanken apply direct distribution through their branches, online banking, and mobile banking. These distribution channels are fully integrated through data centers to avoid redundancy. Both banks emphasize the importance of local branches, as personalized advisory service is an important part of keeping customers satisfied. Some customers prefer advisory or self-service through online- or mobile banking. These are the most cost-efficient ways of serving bank customers. Gradually, a larger part of the customers' needs and problems will be handled by online platforms to further reduce costs. As a consequence, online- and mobile banking will become the common way of handling customer inquiries. 


\subsubsection{Customer Relationships}

New technologies change the characteristics of the average customer relationship. However, both banks stress the importance of a personalized relationship to customers as a possibility to differentiate products and services. Unfortunately, a large portion of the administrative expense block is dedicated to this personal relationship/assistance. The customers' confidence in the guidance and the offerings from the bank are important aspects that frame all interactions with the customers. It is important to promote a culture within the organization that focuses on customer satisfaction rather than revenue, as customer satisfaction to some degree is linked to increased revenues (Ittner, Larcker, \& Taylor, 2009; Keiningham, Perkins-Munn, Aksoy, \& Estrin, 2005). This implies that neither bank uses strict sales plans of (unnecessary) products, as this might jeopardize customers' perception of the bank (de Moubray, 1991).

\subsubsection{Revenue Streams}

Revenue streams describe the different ways an organization generates revenues from customer segments through value propositions. Only a small part of the revenues arises from one-time payments, as both banks focus on long-term relationships. Accordingly, the revenue generation is characterized by customer payments from the continuing business relation. Regarding both the private and corporate segment, the revenue generation arises from interest payments, subscription fees, access to online- and mobile banking, usage fees, as well as usage of onlineand mobile banking. But the main part of the revenue is interest income from lending products.

\subsubsection{Key Resources}

The first part of the infrastructure management consists of the key resources. Key resources are the most important assets required to make the other parts of the business model work (Osterwalder \& Pigneur, 2010). The key physical assets are the IT infrastructure and the location of branches to ensure convenience for the customers. The key intellectual assets are the customer relationship management database. This ensures sufficient knowledge about the customers and the partnerships with different suppliers. The single most important key resource is the employees. These are crucial for achieving high customer satisfaction and a high reduction of loan losses. As a financial institution is a service organization where the production is created in cooperation with the customer, the employees should be highly skilled and motivated. Lastly, an important key resource is the funding market.

\subsubsection{Key Activities}

Key activities are the actions that determine operational success. The main activity is financial advisory of private and corporate customers. Again, this is crucial when it comes to achieving high customer satisfaction and a low degree of loan losses. Less important activities are the innovation of a competitive product portfolio and IT infrastructure, as these are mainly developed through partner unions in smaller banks.

\subsubsection{Key Partnerships}

As mentioned above, the key partners of DLB and Handelsbanken are their partner unions. Also, DLB and Handelsbanken make use of Data Centres, BankData, BEC, and TotalKredit (mortgage provider). Relying on these standardized solutions is crucial to both efficiency considerations and acquisition of products and services. Other key partners are pension- and insurance companies, which deliver non-core products. Lastly, the banks define the providers of funds as the third key partner.

\subsubsection{Cost Structure}

The cost structure of DLB's and Handelsbanken's business model is neither cost- nor revenue-driven but something in between. Operating costs are certainly a competitive parameter. But trying to minimize costs of key resources can only be economically beneficial in the short run. In the long run, implications might harm the organization. The avoidable costs in this business model relate to the employee costs and the costs of data centers. The employee costs are fixed in the short run, while the costs to the data center are split between fixed and variable 
costs. The allocation basis of the general development costs depends on the number of employees. For both DLB and Handelsbanken, the employee costs constitute the most significant parameter. The share of the data center costs on the total cost is larger in DLB than in Handelsbanken due to the larger size of the former. Another unavoidable cost is the interests paid to depositors. The interests paid could be increased in the future, as the share of bank deposits in relation to the total financial position is increased due to its favorable treatment in the new regulatory ratios (cf. European Union Capital Requirement Regulation, 2013, §421 LCR retail deposits, and §427 NSFR retail deposits).

\subsection{Similar Strategic Priorities}

Overall, the differences between the business models of DLB and Handelsbanken can be characterized as minor. These differences are due to a significant size difference between the two banks, but not a result of different approaches regarding the basic foundation of the business model. It is now relevant to see if this is also the case for their strategies. Casadesus-Masanell and Ricart (2010, p. 196) refer to strategy as "the choice of business model through which the firm will compete in the marketplace." In line with previous literature on the strategic priorities of banks (Hagel \& Singer, 1999; Treacy \& Wiersema, 1993), we divide the nine building blocks into four strategic pillars (products, customer interface, infrastructure management, and financial aspects) and prioritize them (cf. Table 2). It is our goal to set up the base for a discussion regarding similarities and differences of business models in banks and the weight assigned to each strategic priority.

Table 2: Classification and Prioritization of the Nine Building Blocks

\begin{tabular}{|l|c|c|}
\hline Strategic Priority & Strategic Pillars & Business Model Building Blocks \\
\hline 1. & Financial Aspects & Cost structure; revenue streams \\
\hline 2. & Customer Intimacy & Customer segments; channel; customer relationships \\
\hline 3. & Product Leadership & Value propositions \\
\hline 4. & Operational Excellence & Key resources; key activities; key partnerships \\
\hline
\end{tabular}

The four pillars correspond to the notions of Hagel and Singer (1999) and Treacy \& Wiersema (1993). Naturally, the shareholder perspective is by definition the most important one for a for-profit organization (Lueg, 2008, 2010). However, to develop a successful business model and strategy, it is important to balance the weight given to each of the three pillars. Organizations that do not accept any trade-offs will experience that these areas compete against each other. With respect to the non-financial blocks, the most important one for banks is customer intimacy. This is due to the service-industry-nature of banks: they develop their products during the contact with the customer. For this reason, the quality of this 'production phase' will naturally feed into overall customer satisfaction. Both DLB and Handelsbanken have a focus on operational excellence (cost control) even though the characteristics of the focuses are not identical. Process and general cost control is important, but control should not be at the expense of customer intimacy. Therefore, it is subordinated to customer intimacy. Rated last is product leadership, because it is extremely costly to be a first mover on the market as banking products are easy to copy. Overall, we can conclude that the strategic priorities of the two banks are similar since similar weights are assigned to each pillar. This leaves only tactical choices as a potential reason for differences in their performances.

\section{DISCUSSION OF TACTICAL DIFFERENCES}

\subsection{Different Strategic Choices within the Same Business Models}

The business models of organizations may target the same customers with similar products and services. Yet, their tactical choices and resulting performance do not have to be identical (Casadesus-Masanell \& Ricart, 2010; Zott \& Amit, 2008). Handelsbanken and DLB make different tactical choices within their business models. We elaborate on them in the following.

\subsubsection{Response to Regulation}

Regulations lower the risk of bankruptcy of financial institutions and influence the tactical choices banks have on their business model. For instance, the degree to which responsibility can be delegated scales with the size 
of the bank. The reason for this is that a single branch manager giving out a large, defaulting loan can jeopardize the whole bank if it is the size of DLB, while a bank like Handelsbanken could absorb such a loss. Note that regulation can also be a driver for more centralization as some regulatory ratios have to be fulfilled by every single subsidiary of a banking group (cf. European Union Capital Requirement Regulation, $2013 \S 415$ LCR for each entity). In this context, the number of regulatory ratios and thus complexity scale with the number of subsidiaries.

A further regulatory requirement is that top management has to evaluate all budgets (The Danish Financial Supervisory Authority, 2010) according to Chapter 2, §2, Subsection 3. Banks can be exempt according to BEK 1325 Chapter 1, $\S 1$, Subsection 3 due to size; i.e., being too large, which is the case for Handelsbanken but not for DLB. Therefore, DLB is not allowed to delegate as much responsibility to the lower level managers as Handelsbanken.

\subsubsection{Planning and Budgeting}

Different from DLB, Handelsbanken abandoned the traditional annual budget in the beginning of the 1970s. This was mainly the result of two reasons: First, the budgeting process consumed considerable resources. Second, the budget was seen as a 'contract' that suppressed new ideas and committed the individual branches to act according to old (maybe outdated) knowledge during the budget year (Hope \& Fraser, 1997; Lueg \& Lu, 2012, 2013). Decentralization seemed an appropriate response by which to address these shortcomings of budgeting (Handelsbanken, 2013a; Wallander, 1999, 2003). Instead of bureaucratic central control, individual branches today have decision-making authority; e.g., a significantly larger credit approval limit than that of their competitors. Also, the branch manager has the full responsibility for the employees, interior decoration, sponsorships etc. (Wallander, 2003). The budgets are replaced by less comprehensive periodic business plans. These are prepared by the branch managers, not the corporate controlling unit. Still, some restrictions apply; e.g., the number of employees is restricted by the branch size, and there are tight cost policies for furnishing branches. This organizational setup educates branch managers to become entrepreneurs who align their personal interest with the interest of Handelsbanken's shareholders.

\subsubsection{Evaluation and Control}

The culture of control differs between the two banks. DLB applies traditional periodic diagnostic controls (Simons, 1995). Handelsbanken's lack of budgets emphasizes ongoing cultural controls where employees have to achieve certain targets (Merchant \& Van der Stede, 2007). Thus, it is important for the organization to establish a culture which supports this close monitoring since some might find this permanent transparency threatening. Furthermore, it is important that managers are capable of monitoring performance and know how to sanction or encourage employees who are not performing as they should. At the same time, Handelsbanken has eliminated its sales plans, bonus schemes, etc. that encourage the advisers to sell products the customers do not need. This is described as a main driver for achieving customer satisfaction (Handelsbanken, 2013b).

\subsubsection{Customer Accounting and Accounting for Customers}

The banks intend to account for customers in the same way but cannot always do so due to contextual conditions. First, both banks attempt to apply a policy where they focus on profitable and financially sound customers. Having such customers in the portfolio automatically increases customer satisfaction. This is because those who can actually pay back their loans with ease feel that they have a better relationship with the bank and are thus more satisfied (Handelsbanken, 2013b). However, Handelsbanken can be more consistent in applying a tight credit policy. DLB faces the dilemma that their reputation may be damaged if they refuse risky customers. DLB is seen as the "bank of the town" that is deemed to have responsibility to support local business. This introduces a regional bias in their portfolio structure that manifests as limited diversification.

On the other hand, the "bank of the town" image is an advantage DLB has over Handelsbanken. Handelsbanken also tries to apply the "church tower principle" by directing the customers to the branch closest to their homes. But due to DLB's roots in its community, DLB's customers appear to be among the most loyal a bank can have. 


\subsubsection{Leadership Approach}

When an organization decides to delegate responsibility as in Handelsbanken, the managers have to have strong leadership capabilities. According to the Situational Leadership Model (Hersey et al., 1979), managers must be confident that their employees are reflective individuals who are capable of handling the task. Also, leadership managers are not afraid of losing control.

Furthermore, the employees should fit the leadership style. Since the employees in Handelsbanken are used to having more responsibility, they are also more able, willing, and confident to take on complex tasks. If either delegating managers or the relevant employees do not fit these assumptions, it is likely that the involved actors will resist the change or be demotivated (Lawrence, 1969). In any case, it is important to make employees part of the change by communicating the aims and the process of change (Buelens, Sinding, Waldstrøm, Kreitner, \& Kinecki, 2011). As a last remark, the delegation of authority to employees helps in building a bank's next generation of top managers.

\subsection{Generalizability and Limitations}

Our findings are only exploratory. As DLB is a 'typical' bank, our findings are likely to have implications for other small and medium sized banks, not only in Scandinavia. Yet, even banks significantly similar to DLB should be aware that this study has not addressed all aspects of DLB. Hence, it is important for any bank to recognize potential differences with respect to the implementation of 'The Handelsbanken Way.' The research is further limited by not including a case from a highly centralized bank.

Also, the use of only one key informant poses a restraint. Even though we have carefully selected knowledgeable individuals such as a CEO and a branch manager, their views and experiences might still diverge from the ones of other actors within their respective banks.

\section{CONCLUSION}

This study shows to which extent small and medium sized banks can profit from making tactical choices that are related to 'The Handelsbanken Way' of decentralization. Our study reveals that both the strategies and the business models of Handelsbanken and DLB are quite similar. They target roughly the same customers, offer almost identical products, employ similar key resources and activities, and share similar cost structures.

In conclusion, the stricter regulation on decentralization for DLB poses challenges to the adoption of the decentralized model of Handelsbanken. Therefore, DLB's traditional planning and control policies cannot be substituted with the budget abandonment and cultural control of Handelsbanken. In a similar manner, it is not possible to simply transfer Handelsbanken's trust-based leadership style to DLB, as such a (re-)organization requires a mental shift every manager may not be able to perform. Lastly, the strong local roots of DLB cause different compositions of the customer portfolio. DLB and Handelsbanken may have the same business models, but the tactical choices implied by decentralization cause the implementations of these business models to be quite different.

\section{AUTHOR INFORMATION}

Morten Kousgaard Larsen is enrolled in a master's degree program in economics and business administration (Management Accounting and Control) at Aarhus University, School of Business and Social Sciences. Currently, he works part time in Corporate Finance at Arla Foods, specifically with Strategic Finance and business analysis. His interests within research are 'business analysis and optimization' and 'performance management.'

Jacob Lange Nissen currently studies a master's degree in Management Accounting at Aarhus University, School of Business and Social Sciences. Simultaneously, he works part time as a controller in a consultancy in Aarhus, where he primarily works with performance measurement and financial controlling within the organization. 
Rainer Lueg is an Associate Professor for Management Accounting \& Control at Aarhus University, Department of Economics and Business. Previously, he worked as a consultant with McKinsey \& Company. He has published in a number of journals across fields, including Academy of Management Learning \& Education, Management Accounting Research, and Business Strategy \& the Environment. His research interests include performance measurement and long-range planning. E-mail: rlueg@asb.dk (Corresponding author)

Christian Schmaltz is an Assistant Professor for Banking and Banking Regulation Aarhus University, Department of Economics and Business. Previously, he worked as a consultant with two London-based risk management practices. He has published in a number of journals across fields, including Journal of Banking and Finance, Journal of Insurance Regulation, and Journal of Financial Transformation. His research interests include bank management and banking regulation. E-mail: chsch@asb.dk or christian.schmaltz@tninstitute.eu

Joachim Røjkjær Thorhauge currently studies Management Accounting and Control at Aarhus University, School of Business and Social Sciences. Alongside, he works in Business Development at Vero Moda, Bestseller. His research interests include management control and performance management, with a specific focus on the management of a company.

\section{REFERENCES}

1. Amit, R., \& Zott, C. (2001). Value creation in e-business. Strategic Management Journal, 22(6-7), 493520.

2. Atkinson, A. A., \& Kaplan, R. S. (1998). Decentralization Advanced management accounting (pp. 288304). Upper Saddle River, NJ: Prentice Hall International.

3. Buelens, M., Sinding, K., Waldstrøm, C., Kreitner, R., \& Kinecki, A. (2011). Organisational behaviour. New York, NY: McGraw-Hill Higher Education.

4. Carter, N. M., \& Cullen, J. B. (1984). A comparison of centralizationl decentralization of decision making concepts and measures. Journal of Management, 10(2), 259-268.

5. Casadesus-Masanell, R., \& Ricart, J. E. (2010). From strategy to business models and onto tactics. Long Range Planning, 43(2-3), 195-215. doi: 10.1016/j.lrp.2010.01.004

6. Chesbrough, H., \& Rosenbloom, R. S. (2002). The role of the business model in capturing value from innovation: Evidence from Xerox Corporation's technology spin-off companies. Industrial and Corporate Change, 11(3), 529-555. doi: 10.1093/icc/11.3.529

7. Danish_Bankers_Association. (2007). Konkurrencen i banksektoren. Retrieved 1 March 2013 from http://www.finansraadet.dk/politik/analyser/konkurrencen-i-banksektoren.aspx

8. Danish_Bankers_Association. (2013a). Banker presses på overskuddet. Retrieved 1 March 2013 from http://www.finansraadet.dk/Politik/Pages/analyser/banker-presses-paa-overskuddet.aspx

9. Danish_Bankers_Association. (2013b). De største pengeinstitutter. Retrieved 1 March 2013 from http://www.finansraadet.dk/Tal--Fakta/Pages/statistik-og-tal/de-stoerste-pengeinstitutter.aspx

10. de Moubray, G. (1991). Banking is not like selling toothpaste. Long Range Planning, 24(5), 68-74. doi: http://dx.doi.org/10.1016/0024-6301(91)90253-K

11. EPSI. (2012). Kundetilfredshedsanalyse. København: EPSI Danmark.

12. European Union Capital Requirement Regulation, as of 26/6/2013 (2013).

13. Finanswatch. (2013). Handelsbanken tjener fortsat godt i Danmark. Retrieved 1 March 2013 from http://finanswatch.dk/Finansnyt/Pengeinstitutter/article5154761.ece

14. Flick, U. (2009). An introduction to qualitative research (4th ed.). Thousand Oaks, CA: Sage.

15. Fredrickson, J. W. (1986). The strategic decision process and organizational structure. Academy of Management Review, 11(2), 280-297.

16. Goutas, L., \& Lane, C. (2009). The translation of shareholder value in the German business system: A comparative study of DaimlerChrysler and Volkswagen AG. Competition \& Change, 13(4), 327-346.

17. Hagel, J., \& Singer, M. (1999). Unbundling the corporation. Harvard Business Review, 77(2), 133-144.

18. Handelsbanken. (2013a). Drop budgetterne - og slip medarbejderne fri. Retrieved 1 July 2013 from http://www.handelsbanken.dk/shb/inet/icentda.nsf/vlookuppics/handelsbankendk_drop_budgetterne/\$file/d rop_budgetterne.pdf 
19. Handelsbanken. (2013b). Historie. Retrieved 1 July 2013 from http://www.handelsbanken.dk/shb/inet/icentda.nsf/vlookuppics/handelsbankendk_handelsbankenshistorie/\$ file/handelsbankenshistorie.pdf

20. Hersey, P., Blanchard, K. H., \& Natemeyer, W. E. (1979). Situational leadership, perception, and the impact of power. Group \& Organization Management, 4(4), 418-428.

21. Hirst, M. K. (1981). Accounting information and the evaluation of subordinate performance: A situational approach. Accounting Review, 56(4), 771-784.

22. Hope, J., \& Fraser, R. (1997). Beyond budgeting: Breaking through the barrier to 'the third wave'. Management Accounting, 75(11), 20-23.

23. Ittner, C., Larcker, D., \& Taylor, D. (2009). Commentary-The stock market's pricing of customer satisfaction. Marketing Science, 28(5), 826-835.

24. Keiningham, T. L., Perkins-Munn, T., Aksoy, L., \& Estrin, D. (2005). Does customer satisfaction lead to profitability?: The mediating role of share-of-wallet. Managing Service Quality, 15(2), 172-181.

25. Lawrence, P. R. (1969). How to deal with resistance to change. Harvard Business Review, 47(1), 166-175.

26. Lee, H., \& Whang, S. (1999). Decentralized multi-echelon supply chains: Incentives and information. Management Science, 45(5), 633-640.

27. Lueg, R. (2008). Value-based management: Empirical evidence on its determinants and performance effects. Vallendar: WHU Otto Beisheim School of Management.

28. Lueg, R. (2010). Value-based management - Antecedents and performance effects. In K. Pantz (Ed.), Summa Cum Laude 2008: Wirtschaftswissenschaften (pp. 284-285). Darmstadt: Roter Fleck Verlag.

29. Lueg, R., Clemmensen, S. N., \& Pedersen, M. M. (2013). The role of corporate sustainability in a low-cost business model - A case study in the Scandinavian fashion industry. Business Strategy and the

Environment (forthcoming).

30. Lueg, R., \& Lu, S. (2012). Improving efficiency in budgeting - An interventionist approach to spreadsheet accuracy testing. Problems and Perspectives in Management, 10(1), 32-41.

31. Lueg, R., \& Lu, S. (2013). How to improve efficiency in budgeting - The case of business intelligence in SMEs. European Journal of Management, 13(2), 109-120.

32. Lueg, R., Nedergaard, L., \& Svendgaard, S. (2013). The use of intellectual capital as a competitive tool: A Danish case study. International Journal of Management, 30(2), 217-231.

33. Magretta, J. (2002). Why business models matter. Harvard Business Review, 80(5), 86-92.

34. March, J. G., \& Simon, H. A. (1958). Organizations. New York, NY: Wiley \& Sons.

35. Marginson, D., \& Ogden, S. (2005). Coping with ambiguity through the budget: the positive effects of budgetary targets on managers' budgeting behaviours. Accounting, Organizations and Society, 30(5), 435456.

36. Merchant, K. A., \& Van der Stede, W. A. (2007). Management control systems: Performance measurement, evaluation and incentives (2nd ed.). Upper Saddle River, NJ: Prentice Hall.

37. Niro_Invest_APS. (2012). Den Danske Pengeinstitutsektor 2012. Retrieved 1 June 2013 from http://dkniroinvest.b2bglobal.com/?pid=58

38. Osterwalder, A., \& Pigneur, Y. (2005). Clarifying business models: Origins, present, and future of the concept. [Article]. Communications of AIS, 2005(16), 1-25.

39. Osterwalder, A., \& Pigneur, Y. (2010). Business model generation: A handbook for visionaries, game changers, and challengers. New York, NY: John Wiley \& Sons.

40. Pasiouras, F., Tanna, S., \& Gaganis, C. (2011). What drives acquisitions in the EU banking industry? The role of bank regulation and supervision framework, bank specific and market specific factors. Financial Markets, Institutions \& Instruments, 20(2), 29-77.

41. Pokutta, S., \& Schmaltz, C. (2011). Managing liquidity: Optimal degree of centralization. Journal of Banking \& Finance, 35(3), 627-638.

42. Ryan, B., Scapens, R. W., \& Theobald, M. (2002). Research methods and methodology in finance and accounting (2nd ed.). Stamford, CT: Cengage Learning.

43. Schaeck, K., \& Cihák, M. (2012). Banking competition and capital ratios. European Financial Management, 18(5), 836-866.

44. Simons, R. (1995). Levers of control. Boston, MA: Harvard University Press. 
45. The_Danish_Financial_Supervisory_Authority. (2010). Bekendtgørelse om ledelse og styring af pengeinstitutter. Retrieved 1 March 2013 from https://www.retsinformation.dk/Forms/ R0710.aspx?id=134459

46. Thompson, J. D. (1967). Organizations in action. New York, NY: McGraw-Hill.

47. Treacy, M., \& Wiersema, F. (1993). Customer intimacy and other value disciplines. Harvard Business Review, 71(1), 84-93.

48. Wallander, J. (1999). Budgeting-An unnecessary evil. Scandinavian Journal of Management, 15(4), 405421.

49. Wallander, J. (2003). Decentralisation - Why and how to make it work. Stockholm: SNS Förlag.

50. Weill, L. (2013). Bank competition in the EU: How has it evolved? Journal of International Financial Markets, Institutions and Money, 26, 100-112.

51. Wong, E. M., Ormiston, M. E., \& Tetlock, P. E. (2011). The effects of top management team integrative complexity and decentralized decision making on corporate social performance. Academy of Management Journal, 54(6), 1207-1228.

52. Yin, R. K. (2009). Case study research: Design and methods (4th ed.). Thousand Oaks, CA: Sage.

53. Zott, C., \& Amit, R. (2008). The fit between product market strategy and business model: Implications for firm performance. Strategic Management Journal, 29(1), 1-26.

54. Zott, C., Amit, R., \& Massa, L. (2011). The business model: recent developments and future research. Journal of Management, 37(4), 1019-1042. 
NOTES 